\title{
SEROPREVALENCE OF BRUCELLOSIS IN SLAUGHTERED ANIMALS AT ASSIUT GOVERNORATE
}

A.M. KORIEM; S. H. AL-HABATY; N.H. MAKAR and H.A. ABD EL-KADER

Animal Health Research Institute, Assiut Branch.

\section{ABSTRACT}

Received at: 11/3/2013

Accepted:3/4/2013
The aim of this study was to investigate the Seroprevalence of brucellosis among the slaughtered food animals at Assiut Governorate abattoirs, Egypt. A total of 896 serum samples (747 from cattles \& 149 from buffaloes) from different localities in Assiut Governorate abattoirs were tested for detection of the brucella antibodies. Results obtained by buffer acidified plate antigen test (BAPAT) and Rose Bengal plate test (RBT) as screening tests indicated a positive reactors percentage 2.19, 2.24, 2.14 and $4.0 \%$ in Assiut, Abnoub, EL-Qusseia and Dairout respectively. The brucella positive reactors were subjected to confirmation by tube agglutination test (TAT) and Rivanol test (Riv.T). The present study revealed that RBT and BAPAT were the most sensitive as screening tests for diagnosis of brucella in slaughtered animals.

Key Words: Brucellosis, Slaughtered Animals, Seroprevalence

\section{INTRODUCTION}

Brucellosis is a world-wide problem of both Public health and economic importance. It is of public health significance not only because of direct and indirect transmission of the disease from infected animals to man, but also because it causes serious diminution of much needed animal protein which are essential to human health (Junaidu et al., 2011).

Brucellosis is an important re-emerging zoonotic disease with a worldwid distribution. It stills an uncontrolled serious public health problem in many developing countries including Egypt (Ali, 1998 and Mantur and Amarnath, 2008). It affects all species of live stock and causing sever economic loss (Stack et al., 2002).

The interest for brucellosis has increased since Brucella species has been identified as a potential biological weapon (Blasco and Molina-Flores, 2011) For several decades it has been recognized as a significant public health problem in the Middle East and recent reports suggested that its incidence is increasing in both ruminants and humans (Benkirane, 2006 and Refai, 2002) and that currently applied control measures may not be capable of reducing the levels of infection in ruminants (Hegazy et al., 2009).

In Egypt, Brucella melitensis biovar 3 is considered to be the predominant species of Brucella isolated from humans and animals (Refai, 2002) Outbreaks in cattle due to $B$. melitensis have become a worldwide emerging problem particularly difficult to control due to the lack of knowledge on the epidemiology in this host species and of an effective vaccine (Alvarez et al., 2011).

Bacterial load in animal muscle tissues is low but consumption of under cooked traditional delicacies such as liver has been implicated in human infection (Tikare et al., 2008). Other means of human infection include skin abrasions or inhalation of airborne animal manure particles. Contamination of skin wounds may be a problem for persons working in slaughterhouses or meat packing plants or for veterinarians (Awad, 1998).

Although brucellosis and its means of transmission were discovered over 100 years ago, the disease is a world wide problem, predominantly so in the developing countries. The transmission of brucella infection and its prevalence in a region depends upon several factors like food habits, methods of processing (Mantur et al., 1996).

Brucella melitensis is the most invasive species and produces the most serious infection in human and animals (Hinic et al., 2009). Brucella melitensis was wide spread in slaughtered food animal in Beni-suef abattoir as well as the lymph node showed the high incidence as compared with edible offal (spleen, liver, kidney, heart and lung). This offal constitute public health hazard for handlers and consumers. Strict authorized regulations for slaughterhouses with condemnation of edible offal of Brucella positive slaughtered animals (Fatma and Emad, 2010). 
Diagnosis of Brucella spp. infection is mainly based on the detection of antibodies in serum by serological tests. Rose Bengal test (RBT) was the most accepted test worldwide for this purpose (Davies, 1971).

BAPAT and RBPT serological tests revealed the highest rate of sensitivity that guides us to use these tests as screening tests on animal brucellosis. RIV. test shows the highest rate of specificity that bearing in mind the BAPAT and RBT positive samples should be confirmed by this test (Montasser et al., 2011).

In Egypt, brucellosis is still an endemic disease had reported among domestic animals inspite of the persistance of national surveillance and control programe through test and slaughter, but human brucellosis is under estimated (Nawar et al.,1992).

Therefore this work was done to estimate the seroprevallance of Brucella sp. Among slaughtered food animals in Assiut Governorate in relation to locality, animal species and sex.

\section{MATERIALS and METHODS}

- Samples Collection:

A total 896 blood samples were collected from the slaughtered animals (cattles \& buffaloes) under strict hygienic condition from different localities (Assiut, Abnoub, EL-Qussiea \& Dairout). Blood samples were sent to the laboratory as soon as possible, were allowed to clot and the sera were obtained by centrifugation and stored at $-20 \mathrm{C}^{\circ}$ until performing serological tests.

\section{- Serological Examination :}

All used four antigens were obtained from Veterinary Serum and Vaccine Research InstituteAbbasia, Cairo-Egypt.

All sera were screened for antibodies against brucella by BAPAT as discribed by Angus and Barton (1984) and RBT as discribed by Alton et al. (1988).

All positive serum samples were confirmed by TAT and Riv.T as described by Alton et al. (1988).

\section{RESULTS}

All data obtained through the investigation were illustrated in tables 1-4.

Table 1: The incidence of brucella by different serological tests in relation to locality.

\begin{tabular}{cccccccccc}
\hline \multirow{2}{*}{ Locality } & \multirow{2}{*}{ Total } & \multicolumn{2}{c}{ RBPT } & \multicolumn{2}{c}{ BAPAT } & \multicolumn{2}{c}{ TAT } & \multicolumn{2}{c}{ Riv.T } \\
\cline { 2 - 10 } & & $+\mathrm{ve}$ & $\%$ & $+\mathrm{ve}$ & $\%$ & $+\mathrm{ve}$ & $\%$ & $+\mathrm{ve}$ & $\%$ \\
\hline Assiut & 137 & 3 & 2.19 & 3 & 2.19 & 3 & 2.19 & 3 & 2.19 \\
\hline Abnoub & 357 & 8 & 2.24 & 8 & 2.24 & 7 & 1.96 & 6 & 1.68 \\
\hline El-Qusseia & 327 & 7 & 2.14 & 7 & 2.14 & 6 & 1.83 & 4 & 1.22 \\
\hline Dairout & 75 & 3 & 4.0 & 3 & 4.0 & 2 & 2.66 & 2 & 2.66 \\
\hline Total & 896 & 21 & 2.34 & 21 & 2.34 & 18 & 2.09 & 15 & 1.67 \\
\hline
\end{tabular}

Table 2: Incidence of brucella among slaughtered animals in relation to species.

\begin{tabular}{cccccccc}
\hline \multirow{2}{*}{ Locality } & \multicolumn{5}{c}{ Cattle } & \multicolumn{5}{c}{ Buffalo } & \multirow{2}{*}{ Total } \\
\cline { 2 - 7 } & Total & $+\mathrm{ve}$ & $\%$ & Total & $+\mathrm{ve}$ & $\%$ & \\
\hline Abnoub & 290 & 2 & 0.69 & 67 & 4 & 5.98 & 357 \\
\hline Assiut & 114 & 3 & 2.63 & 23 & 0 & 0 & 137 \\
\hline El-Qusseia & 268 & 3 & 1.12 & 59 & 1 & 1.69 & 327 \\
\hline Dairout & 75 & 2 & 2.67 & 0 & 0 & 0 & 75 \\
\hline Total & 747 & 10 & 1.34 & 149 & 5 & 3.35 & 896 \\
\hline
\end{tabular}


$\underline{\text { Assiut Vet. Med. J. Vol. } 59 \text { No. } 137 \text { April } 2013}$

Table 3: Seroprevalence of brucellosis among slaughtered animals in relation to sex.

\begin{tabular}{|c|c|c|c|c|c|c|c|c|c|c|c|c|}
\hline \multirow{3}{*}{ Locality } & \multicolumn{6}{|c|}{ Cattle } & \multicolumn{6}{|c|}{ Buffalo } \\
\hline & \multicolumn{3}{|c|}{ Male } & \multicolumn{3}{|c|}{ Female } & \multicolumn{3}{|c|}{ Male } & \multicolumn{3}{|c|}{ Female } \\
\hline & Total & $+\mathrm{ve}$ & $\%$ & Total & $+\mathrm{ve}$ & $\%$ & Total & $+\mathrm{ve}$ & $\%$ & Total & $+\mathrm{ve}$ & $\%$ \\
\hline Abnoub & 283 & 2 & 0.71 & 7 & 0 & 0 & 43 & 2 & 4.65 & 24 & 2 & 8.33 \\
\hline Assiut & 114 & 3 & 2.63 & 0 & 0 & 0 & 12 & 0 & 0 & 11 & 0 & 0 \\
\hline El-Qussesia & 260 & 3 & 1.15 & 8 & 0 & 0 & 57 & 1 & 1.75 & 2 & 0 & 0 \\
\hline Dairout & 0 & 0 & 0 & 75 & 2 & 2.67 & 0 & 0 & 0 & 0 & 0 & 0 \\
\hline Total & 657 & 8 & 1.22 & 90 & 2 & 2.22 & 112 & 3 & 2.68 & 37 & 2 & 5.41 \\
\hline
\end{tabular}

Table 4: Different serological reactions for seroreactive samples.

\begin{tabular}{|c|c|c|c|c|c|c|c|c|c|c|c|c|c|c|c|c|}
\hline \multirow{3}{*}{ Locality } & \multirow{3}{*}{$\begin{array}{c}\text { Total } \\
\text { Reactors }\end{array}$} & \multicolumn{15}{|c|}{ Serological tests } \\
\hline & & \multirow{2}{*}{$\mathrm{RBPT}$} & \multirow{2}{*}{ BAPAT } & \multicolumn{7}{|c|}{ TAT } & \multicolumn{6}{|c|}{ Rivanol } \\
\hline & & & & $1 / 10$ & $1 / 20$ & $1 / 40$ & $1 / 80$ & $1 / 160$ & $1 / 320$ & total & $1 / 25$ & $1 / 50$ & $1 / 100$ & $1 / 200$ & $1 / 400$ & total \\
\hline Abnoub & 8 & 8 & 8 & 1 & 1 & 2 & 1 & 1 & 1 & 7 & 3 & 2 & 0 & 0 & 1 & 6 \\
\hline Assiut & 3 & 3 & 3 & 0 & 1 & 0 & 1 & 0 & 1 & 3 & 1 & 1 & 0 & 0 & 1 & 3 \\
\hline El-Qusseia & 7 & 7 & 7 & 1 & 4 & 1 & 0 & 0 & 0 & 6 & 3 & 1 & 0 & 0 & 0 & 4 \\
\hline Dairout & 3 & 3 & 3 & 0 & 0 & 1 & 0 & 1 & 0 & 2 & 1 & 0 & 0 & 1 & 0 & 2 \\
\hline Total & 21 & 21 & 21 & 2 & 6 & 4 & 2 & 2 & 2 & 18 & 8 & 4 & 0 & 1 & 2 & 15 \\
\hline
\end{tabular}

\section{DISCUSSION}

Bovine brucellosis is included on the OIE (Office International des Epizooties) list of notifiable diseases as a multiple species disease. This obliges OIE member countries to notify the OIE within 24 hours of confirming the presence of bovine brucellosis. OIE-listed diseases are diseases with the potential for international spread, significant mortality or morbidity within the susceptible species and/or potential for zoonotic spread to humans (Anon, 1998).

In the present study, the obtained results revealed that BAPAT and RBT showed high rate of sensitivity as screening tests, these findings agreed with El-Gibaly (1993) and Montasser et al. (2011), while Angus and Barton (1984) and Gall and Nielsen (2004) showed that BAPAT was more sensitive and accurate than the other conventional tests for detection of brucella in bovine serum. This was attributed in part to the instability of some of the antigen preparations used in the other tests. In addition, MacMillan, (1990) reported that the RBT antigen may be deteriorate when repeatedly cycled between refrigerator and room temperature during use. The confirmation with Rivanol test is also recommended due to its high specifity and reliability in detecting the infected cases without serious number of false positive (Huber and Nicoletti, 1986).

The findings of the present study (table 1) revealed that the highest brucellosis incidence was among slaughtered animals in Dairout followed by Assiut localities representing 2.66 and $2.19 \%$ respectively, where Abnoub and El-Qusseia showed low incidence representing 1.68 and $1.22 \%$ respectively, these present findings were in agreement with $\mathrm{Abd}$ El-Hafeez et al. (2001) that give a high risk of 
infection among human in these localities specially veterinarians and abattoir workers.

The obtained results (table 2) revealed that the highest incidence of brucellosis in the examined slaughtered cattle was in Dairout followed by Assiut representing 2.67 and $2.63 \%$ respectively, while ElQusseia and Abnoub representing 1.12 and $0.69 \%$ respectevely. In a similar study done by Montasser et al. (2011) who found that the high incidence of brucellosis in cattle in Dairout, Abnoub and Assiut were 5.3, 5.3 and $4.7 \%$ respectively, while in ElQusseia not recorded any case. These finding revealed that the high incidence of brucellae indicated that the brucella infection was wide spread in diferent species of animals marketed in Assiut Governorate and that result resemples that occured in Damaturu, yobe State in arid zone of north eastern Nigeria, the prevalence rate of brucellosis in slaughtered cattle was $5.7 \%$ (Tijjani et al., 2009).

The gained results (tabl 2) showed that the incidence of brucellosis in slaughtred buffalloe $3.35 \%$ more than that noticed in cattle $1.34 \%$. These finding was in agreement with Fatma and Emad (2010), they found that the incidence of brucellosis in buffalloe was 7.6, 9.0, and $12.5 \%$ at 2004, 2005 and 2006 respectively, while in cattle was 4.0, 3.7 and $4.6 \%$ respectively at Beni- Suef abattoir.

In relation to sex, the obtained results showed that high incidence of brucellosis in female cattle and buffalloe 2.22 and $5.41 \%$ respectively while in male cattle and buffalloe was 1.22 and $2.68 \%$ respectively, these results agreed with Junaidu et al. (2011). They noticed that the higher prevalence recorded in female than that in male at that may be a result from the fact that the foci of infection remain in female, which spread the infection from one animal to another. Similarly, it appears that the female animals are generally more susceptible to brucella infection than the males because of $\mathrm{D}$ erythritol, an alcohol normally found in higher volume in foetal tissue in pregnant females than in seminal vesicles and testes of the males (Keppie et al., 1965) and is known to stimulate the growth of virulant strains of brucella (Williams et al., 1963).

The results obtained in (table 4) were in agreement with Morgan (1971), Cordes and Carter (1979) and Montasser et al. (2011), it is noted that no single test can identify all infected animals at all stages of the disease and therefore a combination of serological tests (BAPAT; RBT; TAT and RIV.T) should be included to reduce the number of both false positive and false negative serological reactions. Therefore, it is of importance to use more than one diagnostic test for the diagnosis of brucellosis.

In conclusion, brucellosis was recorded in slaughtred food animals in Assiut Governorate abattoirs, where the high incidence $2.66 \%$ was recorded in Dairout but the lowest $1.22 \%$ was recorded in EL-Qusseia. Concerning species the high incidence $3.35 \%$ was noticed in buffaloe in comparasion with cattle $1.34 \%$. There was an association between brucella infection and sex, where the high incidence was noticed in female. It acts as a public health hazard for veterinarians, abattoir workers \&butchers. Therefore strict authorized regulations for slaughterhouses and protection of veterinarians, abattoir workers and butchers as well as periodic examination to determine their health status must be done.

\section{REFERENCES}

Abd El-Hafeez, M.M.; Abd El-Kader, H.A.; Ali, M.M.; Bastawrows, A.F. and Sedik, S.R. (2001): Zoonotic Importance of Brucellosis Among Farm Animals and Veterinary Field Employees At Assiut Governorate. Assiut Vet. Med. J., 44(88): 119-135.

Ali, K.H.A. (1998): Granulomatous inflammatory reactions in lymphoreticular tissue and parenchymatous organs. M. V. Sc. Thesis, Cairo University Beni-Suef. community trade in bovine animals and swine.

Alton, G.G.; Jones, L.M.; Angus, R.D. and Verger, J.M. (1988): Techniques for the brucellosis laboratory. Institut National de la Recherche Agronomique, Paris, 190 pp.

Álvarez, J.; Sáez, J.L.; García, N.; Serrat, C.; PérezSancho, M.; González, S.; Ortega, M.J.; Josep, G.; Carbajo, L.; Garrido, F.; Goyache, J. and Dominguez, L. (2011): Management of an outbreak of brucellosis due to $B$. melitensis in dairy cattle in Spain. Res. Veterinary Sci., 90(2): 208-211.

Angus, R.D. and Barton, C.E. (1984): The production and evaluation of a buffered plate antigen for use in a presumptive test for brucellosis. In Proc. 3rd International Symposium on brucellosis, Algiers, Algeria. Dev. biol. Standard., 56: 349-356.

Anon (1998): Conclusions of the Research Subcommittee of the International Embryo Transfer Society (IETS) Import/Export Committee. Review Scientific Techniques (OIE) 17(3): 839.

Awad, R. (1998): Human brucellosis in the Gaza Strip, Palestine; East. Mediterr. Health. J., 4: 225-233.

Benkirane, A. (2006): Ovine and caprine brucellosis: World distribution and control/eradication strategies in West Asia/North Africa region. Small Rumin. Res., 62: 19-25.

Blasco, J.M. and Molina-Flores, B. (2011): Control and Eradication of Brucella melitensis Infection in Sheep and Goats. Veterinary Clinics of North America: Food Animal Practice, 27: 95-104. 
Cordes, D.O. and Carter, M.E. (1979): Persistence of Brucella abortus infection in six herds of cattle under brucellosis eradication. New Zealand Veterinary Journal, 27: 255-259.

Davies, G. (1971): The Rose Bengal Test. Vet. Rec., 88: 447-449. European Council Directive, 1964 .64/432/EEC. On health problems affecting intra- community trade in bovine animals and swine.

El-Gibaly, S.M. (1993): Correlation between serotests and isolation of Brucella melitensis in an infected sheep farm. Proc. 2 Sci. Cong. Socity for cattle Disease, Assiut, pp: 194-203.

Fatma, H.M. Ali and Emad A. Mahdey (2010). Incidence of brucella species in slaughtered food animals and its edible offal at Benisuef,Egypt. Global Veterinaria 5 (5):248-254.

Gall, D. and Nielsen, K. (2004): Serological diagnosis of bovine brucellosis: a review of test performance and cost comparison. Rev. sci. tech. Off. int. Epiz., 23 (3): 989-1002.

Hegazy, Y.M.; Ridler, A.L. and Guitian, F.J. (2009): Assessment and simulation of the implementation of brucellosis control program in an endemic area of the Middle East. Epidemiol. Infect., 137: 1436-1448.

Hinic, V.; Brodard, I.; Thomann, A.; Holub, M.; Miserez, R. and Abril, C. (2009): IS711 based real time PCR assay as a tool for detection of brucella spp. In wild boars and comporasion with bacterial isolation and serology. BMC Vet. Res., 5: 22.

Huber, J.D. and Nicolleti, P. (1986): Comparsion of the results of card, rivanol, complement fixation and milk ring test with the isolation rate of $\mathrm{Br}$. abortus from cattle. Am. J. Vet. Res., 47: 1529-1531.

Junaidu, A.U.; Oboegbulem, S.I. and Salihu, M.D. (2011): Serological survey of Brucella antibodies in breeding herds. J. Microbiol. Biotech. Res.1 (1):60-65.

Keppie, J.W.; Will, A.E. and Smith, H. (1965): British Journal of Experimental Pathology. 46, 104-108.
MacMillan, A. (1990): Conventional serological test. In Animal brucellosis (Nielsen K. and Duncan J.R, eds). CRC Press, Boca Raton, 153-197.

Mantur, B.G. and Amarnath, S.K. (2008): Brucellosis in India-a review. J. Biosci., 33: 539-547.

Mantur, B.G.; Mangalgi, S.S. and Mulimani, M. (1996): Brucella melitensis a sexually transmissible agent; Lancet. pp: 3471763 Erratum in: Lancet 1996; 348970.

Montasser, A.M.; Affi, M.M.; EL-Bayoumy, E.M.; Abdul-Raouf, U.M. and Mohamad, H.A. (2011): Efficiency of serological tests for detection of brucellosis in ruminant at south provinces of Egypt. Global Veterinaria 6 (2):156-161.

Morgan, W.J.B. (1971): Some recent advances in the diagnosis of brucellosis. Irish Vet. J., 25: 214-221.

Nawar, M.; Samour, S. and Wahib, Y. (1992): Detection of brucella agglutinins in normal individuals in Menofia Governorate. Journal of tropical medicine. 2 (2): 129-1.

Refai, M. (2002): Incidence and control of brucellosis in the Near East region. Vet. microbiol., 90: 81-110.

Stack, J.A.; Harrison, M. and Perrett, L.L. (2002): Evaluation of a selective medium for Brucella isolation using natamycin. J. Appli. Microbiol. , 92: 724-728.

Tijjani, A.O.; Musa, H.I.; Ousoumanou, O. and Akintola, O.O. (2009): Prevalence of brucellosis in food animals slaughtered at Damaturu Abattoir, Yobe State, Nigeria .Sahel Journal of Veterinary Sciences. 8, (1).

Tikare, N.V.; Mantur, B.G. and Bidari, L.H. (2008): Brucellar meningitis in an infant - evidence for human breast milk transmission. J. Trop. Pediatr., 54: 272-274.

Williams, A.E.; Keppie, J.W. and Smith, H. (1963): Proceedings of Society of General Microbiology Shetfield, 23-29.

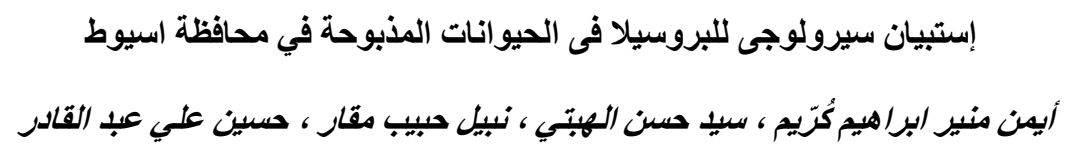

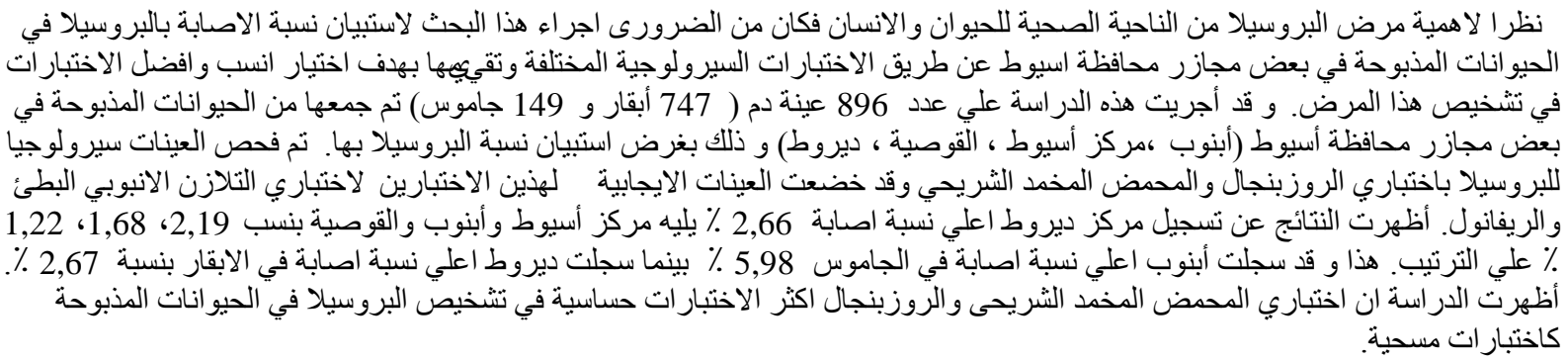


$\underline{\text { Assiut Vet. Med. J. Vol. } 59 \text { No. } 137 \text { April } 2013}$ 
$\underline{\text { Assiut Vet. Med. J. Vol. } 59 \text { No. } 137 \text { April } 2013}$ 